\title{
Structural Properties of Phosphate-Washing Waste Based Geopolymeric Mortars
}

\author{
Rawia Dabbebi, José Barroso de Aguiar, and Samir Baklouti
}

\begin{abstract}
The phosphate ore extraction activities often generate serious environmental problems, particularly those engendered by the phosphate washing waste. The waste was characterized by $\mathrm{X}$ ray fluorescence. The powder was calcined at $700{ }^{\circ} \mathrm{C}$. The calcined and uncalcined samples were then investigated by means of X-ray powder diffraction (XRD). The calcined PWW was activated with sodium hydroxide and sodium silicate to produce geopolymeric materials. The reached results prove to reveal that the present phases in the powder appeared to have a remarkable effect on the result of compressive strength.
\end{abstract}

\section{Keywords}

Phosphate-washing waste - Calcination •

Sodium hydroxide $\cdot$ Sodium silicate $\bullet$ Geopolymeric mortar

\section{Introduction}

Phosphate ore stands as the principal mineral product in Tunisia. This ore is extracted by the Gafsa Phosphate Company (CPG), based in the Tunisian southwest. This ore

R. Dabbebi $(\bowtie) \cdot$ S. Baklouti

Laboratory of Industrial Chemistry, University of Sfax, 3038 Sfax, Tunisia

e-mail: dabbebirawia@gmail.com

S. Baklouti

e-mail: Baklouti.samir@gmail.com

R. Dabbebi · J. B. de Aguiar

C-TAC Research Centre, University of Minho, 4800-058

Guimarães, Portugal

e-mail: aguiar@civil.uminho.pt is composed of fluorapatite, silica, carbonate, gypsum, organic and aluminosilicates materials $[1,2]$. The CPG uses the washing and flotation techniques as means whereby the aluminosilicate, silica and carbonate could be eliminated, and a high percentage $(\sim 80 \%)$ of phosphate ore recovered for commercial use. This process creates a large volume of waste, engendering a real environmental problem.

This waste named phosphate washing waste (PWW), contains quartz, carbonate, aluminosilicate and fluorapatite in respect of the phosphate ore relating mineralogical composition of [3, 4]. Based on the relevant literature, such waste can be explored in different fields as lightweight [5], Ceramic [6], Membrane [7, 8]. The composition of the PWW can be also adequate for the synthesis of other products, particularly, alkali activated materials (geopolymeric mortars).

\section{Materials and Methods}

The phosphate washing waste, as used in this study, is collected from the Metlawi storage pond (Lavrie IV). It was filtered and dried at $105{ }^{\circ} \mathrm{C}$, for $24 \mathrm{~h}$, to remove the water, then crushed and sieved to the grain size of less than $100 \mu \mathrm{m}$. The obtained powder was calcinated at $700{ }^{\circ} \mathrm{C}$ for $2 \mathrm{~h}$ in a muffle furnace at a heating rate of $10{ }^{\circ} \mathrm{C} / \mathrm{min}$.

The powder was, then, characterized via X-ray fluorescence, and the samples via $\mathrm{X}$ ray diffraction (XRD), with $\mathrm{Cu}$ $\mathrm{K} \alpha$ radiation $\lambda=1.54060 \AA$ at $40 \mathrm{kV}$ and $40 \mathrm{Ma}$. The sample was then scanned from $5^{\circ}$ to $60^{\circ}$, at a speed of $0.02 \mathrm{~s}^{-1}$.

The powder was activated using alkaline solutions based on a sodium hydroxide $\mathrm{NaOH}$ solution $10 \mathrm{M}$, and a sodium silicate solution $\mathrm{Na}_{2} \mathrm{SiO}_{3}$. The $\left(\mathrm{Na}_{2} \mathrm{SiO}_{3} / \mathrm{NaOH}\right)$ ratio is of the order of 1 .

The obtained samples of geoplymers mortar were covered and left in the laboratory at ambient temperature, to be characterized at 7 and 28 days. 


\section{Results}

\subsection{Chemical Composition}

The data figuring on Table 1 display the chemical composition of the PWW, revealing that the silica, calcium, aluminum and phosphorus persist in major quantities, while the other elements are present in trace amount.

\subsection{XRD Characterization}

Figure 1 depicts the X-ray diffractgrams of the PWW at 25 and $700{ }^{\circ} \mathrm{C}$. The pattern of PWW at $25{ }^{\circ} \mathrm{C}$ shows the persistence of carbonates, essentially as a calcite, at $3 \AA$. It displayed peaks at $8.76 \AA$, indicating the presence of natural zeolite heulandites as a main aluminosilicate mineral. The PWW also contains a fibrous clay palygorskite, displayed at a peak of $10.09 \AA$, a small amount of quartz with a peak of $3.41 \AA$, and gypsum with a peak of $2.8 \AA$.

The patterns reveal crystalline and amorphous phases, which are important for the powder calcined at $700{ }^{\circ} \mathrm{C}$. It displays that the fluorapatite mineral still appears after calcinations. The curves also indicate that the calcite, palygorskite, and heulandite phases were progressively decreased. This decrease in the calcite phase is related to the decarbonation. For the heulandites, the decrease was related to the temperature effect on the decomposition of the heulandites structure [9]. In addition, reflections of new phase emerge, mainly, $\mathrm{C}_{2} \mathrm{~S}$.

\section{Discussion}

Figure 2 reports the geopolymer $\mathrm{XRD}$ as based on the powder calcined at $700{ }^{\circ} \mathrm{C}\left(\mathrm{G}^{700}\right)$ at 7 and 28 days. The patterns represent a crystallin and amorphous phases. The comparison established between the XRD calcined PWW results at $700{ }^{\circ} \mathrm{C}$ with those of the hardened samples, reveals that the crystalline phases, originally existing at $700{ }^{\circ} \mathrm{C}$ as the Heulandites, palygorskite and anhydrite proved to disappear. Traces of calcite can be detected in the geopolymeric mortars, which could well be the result of either the samples' carbonation, or the quantities persistent in the calcined sample. The patterns appear to reveal that the fluorapatite was unaltered by the alkali solution. In the patterns, the peaks of quartz appear more intensely than those relevant to the calcined materials. This is mainly due to some sand particles used as aggregate, which could not be totally eliminated during the XRD samples' preparation. Furthermore, the crystalline sodium compounds did not appear in the XRD patterns; it could be assumed that the sodium was included in the amorphous geopolymers phase. This $\mathrm{G}^{700}$ associated performance can be approved by the SEM image, as appearing in Fig. 3, highlighting that the mortar was noticeably heterogeneous with a compact structure.

The compressive strength, depicted in Fig. 4, indicates that the geopolymer phases persistent in $\mathrm{G}^{700}$, as resulting from the aluminosilcates phases related destruction, stem from the heulandites and the palygorskite. The evolution of the compressive strength has its interpretation in the amorphous phases and the $\mathrm{C}_{2} \mathrm{~S}$ predominant in the powder calcined at $700{ }^{\circ} \mathrm{C}$. According to Sanchez et al. [10], the $\mathrm{C}_{2} \mathrm{~S}$ prevalent in the alkali medium proves to have a positive effect on the mechanical strength. The reached compressive strength value is of the range of $\sim 11 \mathrm{MPa}$, satisfying the BS 6073 relating requirements, which entails a value $\geq 7$ $\mathrm{MPa}$ of compressive strength for the masonry brick application [11].

\section{Conclusions}

The most obvious finding emanating from the conduction of such a study is that the calcination, as associated with the phosphate washing waste, proved to have a noticeable effect on the phases persistent in the powders.

During the $\mathrm{G}^{700}$ curing time, for 7 and 28 days at ambient temperature, the compressive strength appeared to evolve, due mainly to the presence of the aluminosilicate phases.

The microscopic observation revealed well that the $G^{700}$ turns out to display a noticeable heterogenous and dense structure.

Table 1 The PWW chemical composition

\begin{tabular}{l|l|l|l|l|l|l|l|l|l|l|l}
\hline Oxides & $\mathrm{SiO}_{2}$ & $\mathrm{CaO}$ & $\mathrm{P}_{2} \mathrm{O}_{5}$ & $\mathrm{Al}_{2} \mathrm{O}_{3}$ & $\mathrm{Na}_{2} \mathrm{O}$ & $\mathrm{K}_{2} \mathrm{O}$ & $\mathrm{MgO}$ & $\mathrm{SO}_{3}$ & $\mathrm{Fe}_{2} \mathrm{O}_{3}$ & $\mathrm{~F}_{2} \mathrm{O}$ & $\mathrm{LOI}$ \\
\hline$\%$ & 42 & 26.5 & 10 & 9.77 & 1.12 & 0.673 & 3.09 & 3.39 & 2.31 & 0.96 & 17 \\
\hline
\end{tabular}




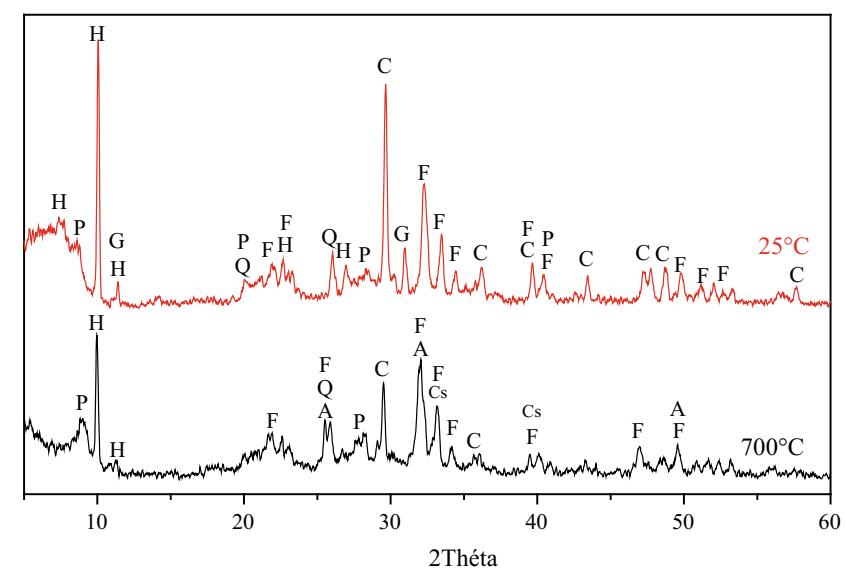

Fig. 1 X ray diffractograms of the PWW uncalcined and calcined $700{ }^{\circ} \mathrm{C}$. C: Calcite, H: Heulandites, G: Gypsum, Q: Quartz, F: Fluorapatite, P: Palygorskite A: Anhydrite, Cs: $\mathrm{C}_{2} \mathrm{~S}$

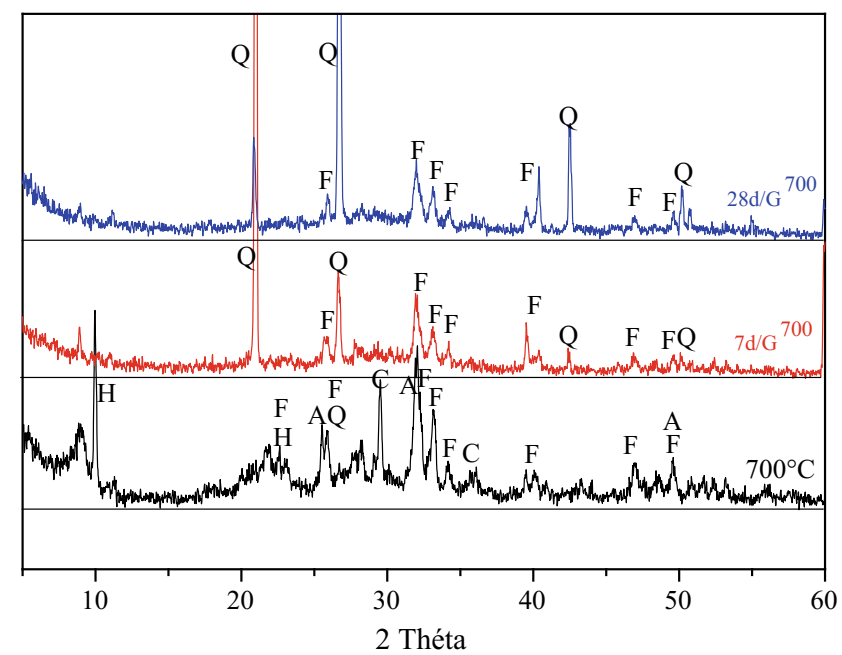

Fig. $2 \mathrm{X}$ ray diffractograms of the PWW calcined $700{ }^{\circ} \mathrm{C}$ and $\mathrm{G}^{700}$

Fig. 3 SEM of $\mathrm{G}^{700}$ at 7 and 28 days
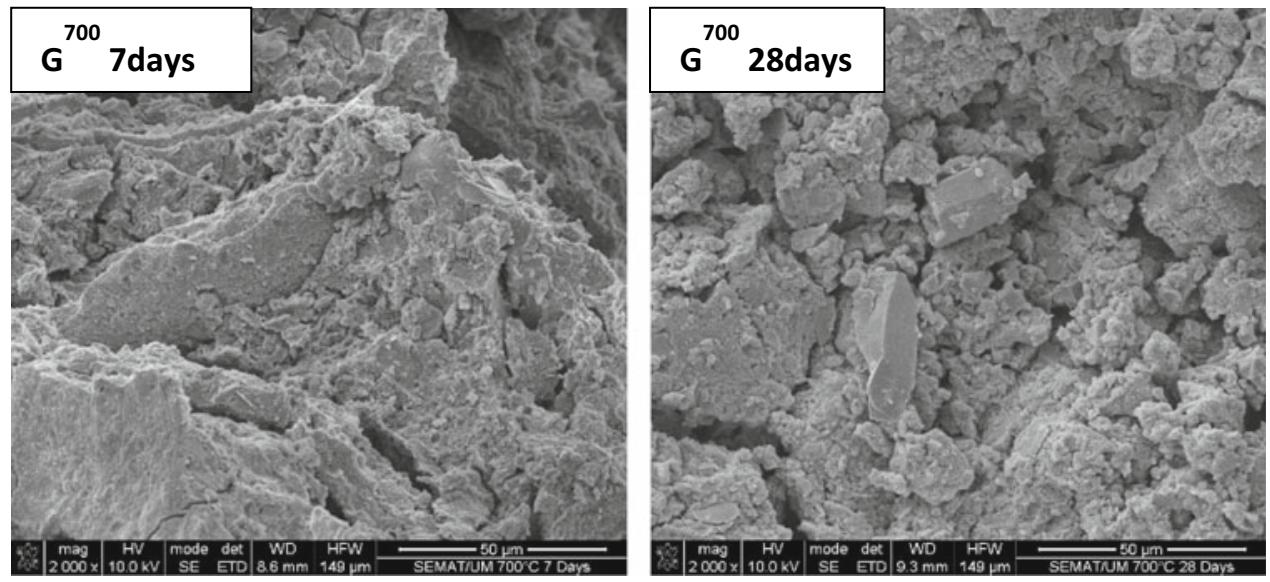


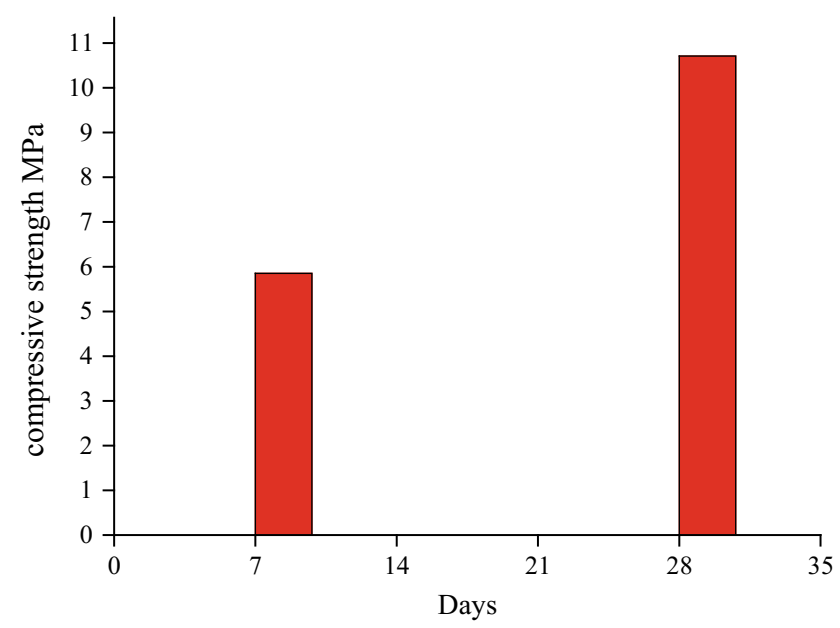

Fig. 4 Compressive strength of the G700

Based on the BS 6073 requirements, the compressive strength reached results make the product fit for masonry applications.

\section{References}

1. Gallala, W., Saïdi, M., el Hajii, S., Zayani, K., Gaied, M.E., Montacer, M.: Characterization and valorization of Tozeur-Nefta phosphate ore deposit (Southwestern Tunisia). Procedia Eng. 138, 8-18 (2016)
2. Boughzala, K., Fattah, N., Bouzouita, K., Hassine, H.B.: Etude minéralogique et chimique du phosphate naturel d'Oum El Khecheb (Gafsa, Tunisie). Rev sci matériaux, Lab LARHYSS 6, 11-29 (2015)

3. Daik, R., Lajnef, M., Amor, S., Ezzaouia, H.: Effect of the temperature and the porosity of the gettering process on the removal of heavy metals from Tunisian phosphate rock. Results Phys 7, 4189-4194 (2017)

4. Elgharbi, S., Horchani-Naifer, K., Ferid, M.: Investigation of the structural and mineralogical changes of Tunisian phosphorite during calcinations. J. Therm. Anal. Calorim. 119, 265-271 (2015)

5. Loutou, M., Hajjaji, M., Mansori, M., Favotto, C., Hakkou, R.: Phosphate sludge: thermal transformation and use as lightweight aggregate material. J. Environ. Manage. 130, 354-360 (2013)

6. Yang, Y., Wei, Z., Chen, Y.-L., Li, Y., Li, X.: Utilizing phosphate mine tailings to produce ceramisite. Constr. Build. Mater. 155, 1081-1090 (2017)

7. Khemakhem, M., Khemakhem, S., Ayedi, S., Cretin, M., Amar, R. B.: Development of an asymmetric ultrafiltration membrane based on phosphates industry sub-products. Ceram. Int. 41, 10343 10348 (2015)

8. Khemakhem, M., Khemakhem, S., Ayedi, S., Amar, R.B.: Study of ceramic ultrafiltration membrane support based on phosphate industry subproduct: application for the cuttlefish conditioning effluents treatment. Ceram. Int. 37, 3617-3625 (2011)

9. Ostrooumov, M., Cappelletti, P., de'Gennaro, R.: Mineralogical study of zeolite from New Mexican deposits (Cuitzeo area, Michoacan, Mexico). Appl. Clay Sci. 55, 27-35 (2012)

10. Sánchez-Herrero, M.J., Fernández-Jiménez, A., Palomo, Á., Klein, L.: Alkaline hydration of C2S and C3S. J. Am. Ceram. Soc. 99, 604-611 (2016)

11. Abdullah, M.M.A., Ibrahim, W.M.W., Tahir, M.F.M.: 12-The properties and durability of fly ash-based geopolymeric masonry bricks. In: Eco-efficient Masonry Bricks and Blocks, pp. 273-287. Woodhead Publishing, Oxford (2015) 